University of Nebraska - Lincoln

DigitalCommons@University of Nebraska - Lincoln

Distribution and environmental limitations of an amphibian pathogen in the Rocky Mountains, USA

\author{
Erin Muths \\ aUSGS-Fort Collins Science Center, muthse@usgs.gov \\ David S. Pilliod \\ Aldo Leopold Wilderness Research Institute, dpilliod@usgs.gov \\ Lauren J. Livo \\ University of Colorado at Boulder
}

Follow this and additional works at: https://digitalcommons.unl.edu/usgsstaffpub

Part of the Earth Sciences Commons

Muths, Erin; Pilliod, David S.; and Livo, Lauren J., "Distribution and environmental limitations of an amphibian pathogen in the Rocky Mountains, USA" (2008). USGS Staff -- Published Research. 131. https://digitalcommons.unl.edu/usgsstaffpub/131

This Article is brought to you for free and open access by the US Geological Survey at DigitalCommons@University of Nebraska - Lincoln. It has been accepted for inclusion in USGS Staff -- Published Research by an authorized administrator of DigitalCommons@University of Nebraska - Lincoln. 


\title{
Distribution and environmental limitations of an amphibian pathogen in the Rocky Mountains, USA
}

\author{
Erin Muths ${ }^{a, *}$, David S. Pilliod ${ }^{b, 1}$, Lauren J. Livo ${ }^{c}$ \\ ${ }^{a}$ USGS-Fort Collins Science Center, 2150 Centre Avenue, Building C, Fort Collins, CO 80526, USA \\ ${ }^{b}$ USDA Forest Service Aldo Leopold Wilderness Research Institute, 790 E Beckwith Avenue, Missoula, MT 59801, USA \\ ${ }^{\mathrm{c} D e p a r t m e n t}$ of Integrative Physiology, University of Colorado, Boulder, CO 80309-0354, USA
}

\section{A R T I C L E I N F O}

\section{Article history:}

Received 30 May 2007

Received in revised form

3 March 2008

Accepted 15 March 2008

Available online 1 May 2008

\section{Keywords:}

Amphibian decline

Batrachochytrium dendrobatidis

Boreal toad

Climate change

Rocky Mountains

Temperature

\begin{abstract}
A B S T R A C T
Amphibian populations continue to be imperiled by the chytrid fungus (Batrachochytrium dendrobatidis). Understanding where $B$. dendrobatidis (Bd) occurs and how it may be limited by environmental factors is critical to our ability to effectively conserve the amphibians affected by Bd. We sampled 1247 amphibians (boreal toads and surrogates) at 261 boreal toad (Bufo boreas) breeding sites (97 clusters) along an $11^{\circ}$ latitudinal gradient in the Rocky Mountains to determine the distribution of $B$. dendrobatidis and examine environmental factors, such as temperature and elevation, that might affect its distribution. The fungus was detected at $64 \%$ of all clusters and occurred across a range of elevations (1030$3550 \mathrm{~m}$ ) and latitudes (37.6-48.6 ) but we detected it in only $42 \%$ of clusters in the south (site elevations higher), compared to $84 \%$ of clusters in the north (site elevations lower). Maximum ambient temperature (daily high) explained much of the variation in Bd occurrence in boreal toad populations and thus perhaps limits the occurrence of the pathogen in the Rocky Mountains to areas where climatic conditions facilitate optimal growth of the fungus. This information has implications in global climate change scenarios where warming temperatures may facilitate the spread of disease into previously un- or little-affected areas (i.e., higher elevations). This study provides the first regional-level, field-based effort to examine the relationship of environmental and geographic factors to the distribution of B. dendrobatidis in North America and will assist managers to focus on at-risk populations as determined by the local temperature regimes, latitude and elevation.
\end{abstract}

Published by Elsevier Ltd.

\section{Introduction}

Chytridiomycosis is a potentially lethal disease of amphibians caused by the amphibian chytrid fungus (Batrachochytrium dendrobatidis $[B d])$ that has been associated with population declines in several amphibian species throughout the world (Daszak et al., 1999; Carey, 2000; Green et al., 2002; Lips et al., 2006). Much of our understanding of the host-pathogen relationship of amphibians and $B d$ in the wild comes from the tropics, particularly Central and South America and Australia. Research in the tropics suggests that mid- to high-elevations provide ideal temperatures for $\mathrm{Bd}$ and amphibian communities at such elevations are more susceptible to infection (Daszak et al., 2003; Berger et al., 2004; Woodhams and Alford, 2005; Drew et al., 2006). Other studies from the tropics suggest that global climate change may be enabling $B d$ to expand its range due to increasingly warm temperatures and moisture at higher elevations (Bosch et al., 2006; Pounds et al., 2006;

\footnotetext{
* Corresponding author: Tel.: +1 970226 9474; fax: +19702269230.

E-mail addresses: erin_muths@usgs.gov (E. Muths), dpilliod@usgs.gov (D.S. Pilliod), Livo@Colorado.edu (L.J. Livo).

${ }^{1}$ Present address: USGS-Forest and Rangeland Ecosystem Science Center, 970 Lusk Street, Boise, ID 83706, USA. 0006-3207/\$ - see front matter Published by Elsevier Ltd. doi:10.1016/j.biocon.2008.03.011
} 
Seimon et al., 2006). Although there is evidence to support this paradigm, it has not been well tested in the northern hemisphere and information on environmental factors limiting the distribution of $\mathrm{Bd}$ in temperate regions is lacking.

The boreal toad (Bufo boreas) is a terrestrial anuran that is distributed widely across western North America. Toads in the Southern Rocky Mountains tend to be found at higher elevations (2615-3385 m, Colorado, Hammerson, 1999) than those in the northern parts of the region (1609-2865 m, in Yellowstone and Grand Teton National Parks (Koch and Peterson, 1995); $2810 \mathrm{~m}$ maximum in Montana (Maxell et al., 2003)). Bufo boreas appears to have suffered increasingly widespread declines along a gradient in the Rocky Mountains from north to south, a pattern possibly associated with the distribution of $\mathrm{Bd}$. For example, Bufo boreas has disappeared from many historic localities, especially in Colorado, over the last 20-30 years (Carey, 1993; Corn, 2000; Corn et al., 2005). Some of these declines have been linked to Bd infection (Muths et al., 2003; Scherer et al., 2005). In contrast, Bufo boreas populations in the Northern Rocky Mountains are perceived to be fairly stable (Corn et al., 2005) and Bd was not found in museum specimens from Montana or Canada prior to 1977 (B. Maxell, Montana Heritage Program, pers. comm.; Ouellet et al., 2005).

Recent studies have provided information on the distribution of Bd in parts of North America (Ouellet et al., 2005, North America; Pearl et al., 2007, Pacific Northwest; Longcore et al., 2007, Northeast), but information on the distribution of $B d$ in the Rocky Mountains is incomplete. These data are needed given that $B d$ is a known pathogen of boreal toads in the laboratory (Blaustein et al., 2005; Carey et al., 2006) and has been isolated from sick and dying toads in the field (Raverty and Reynolds, 2001; Muths et al., 2003). The earliest known occurrences of $B d$ for locations in this study are in Colorado in the mid 1970s (Rana pipiens, Carey, 2000) with later occurrences in Wyoming (Bufo baxteri, Muths et al., 2003), Montana and Idaho (B. boreas and Dicamptodon aterrimus, respectively, D.E. Green, USGS, National Wildlife Health Laboratory, personal communication). Distributional information can provide insights on what species or populations may be resistant to chytridiomycosis and, importantly, what amphibian populations are at risk and should be targeted for conservation actions.

Information on the environmental limitations of $B d$ in the wild is critical to the conservation of amphibians affected by this disease. Variation in environmental factors clearly influences the distribution of $B d$, although there is little empirical data to fully understand the fundamental or realized niche of this pathogen (e.g., Ron, 2005). Laboratory studies have demonstrated that this fungus produces zoospores in vitro between 4 and $25^{\circ} \mathrm{C}$ (Piotrowski et al., 2004), pathogenicity decreases $>23^{\circ} \mathrm{C}$ (Lamirande and Nichols, 2002; Woodhams et al., 2003; Berger et al., 2004) and Bd persists for up to 3 months in moist, sterile river sand (Johnson and Speare, 2003), but little else is known. Although other aspects of climate, such as rainfall, likely play a role in this host-pathogen interaction, we focused on temperature for this study because previous work indicates that temperature is one of the most important environmental parameters determining the persistence and perhaps pathogenicity of the fungus (Piotrowski et al., 2004; Drew et al., 2006; Kriger and Hero, 2007; Kriger et al., 2007). Given global climate change scenarios, and mounting evidence that rising temperatures, diminished snowpack, earlier run-offs and drought are affecting the western United States now (Barnett et al., 2008), it is increasingly important to understand how rising temperatures, particularly at northern latitudes and high altitudes, will affect host-pathogen relationships.

The goals of this study were to (1) determine the current distribution of $\mathrm{Bd}$ at boreal toad breeding localities along a latitudinal gradient, roughly paralleling the continental divide, (2) explore how this distribution may be affected by local climate, and (3) discuss how environment-pathogen relationships may influence declining amphibian species in the Rocky Mountains.

\section{Materials and methods}

\subsection{Sample site selection}

We sampled all known boreal toad breeding sites in Colorado (Jackson, 2005) and 30 boreal toad breeding sites each in Montana and Wyoming randomly from all known breeding localities (C. Peterson and D. Patla, Idaho State University, personal communication, Maxell et al., 2003, Wyoming Game and Fish Department and Wyoming Natural Diversity Database [http:// uwadmnweb.uwyo.edu/wyndd/]). Additional samples were collected opportunistically in Montana, Idaho, Wyoming, and Colorado. The northernmost site was at $48.6^{\circ} \mathrm{N}$. latitude and the southernmost at $37.6^{\circ} \mathrm{N}$. latitude. Sites ranged in elevation from $1030 \mathrm{~m}$ to $3800 \mathrm{~m}$.

\subsection{Site characteristics}

We used a global positioning system ( $\pm 10 \mathrm{~m}$ accuracy) to determine geographic coordinates of each collection site. Elevation data were derived from the national elevation dataset (Gesch et al., 2002). We used program PRISM (2.5 min digital elevation model, Daly et al., 2002, http://www.ocs.oregonstate.edu/ prism/index.phtml) to estimate mean maximum and minimum daily temperatures averaged from 2002 to 2004 (study period weather) and from 1970 to 2005 (long-term climate) during the active season (May-September) for each sample location. We then projected mean maximum and minimum daily temperatures during the active season at each sample location to the year 2100 (Govindasamy et al., 2003).

\subsection{Sample collection and analysis}

We sampled 1151 adult boreal toads and 96 individuals from 5 other species when toads were not abundant or not found at our selected sites. Samples were collected between April and September 2000-2004; most samples (84\%) were collected between May and July. At randomly selected sites, surveyors attempted to capture 10 adult boreal toads to collect ventral skin swabs or scrapings. If toads were unavailable, other adult amphibians were captured and sampled as surrogates. In Colorado, sites were surveyed for boreal toads during the day or night and toe clips or ventral swabs were obtained from up to 20 individual toads per site. Fewer swabs were collected at sites that were sampled opportunistically due primarily to time constraints. 
The ventral surface and the hind foot webbing of each animal was swabbed or scraped $\geqslant 25$ strokes and the sample was placed in $70 \%$ ethanol in a $0.5 \mathrm{ml}$ o-ring vial and labeled. A few individuals were sampled by clipping a single digit. Differences in detectability between the sample methods are not significant (swab versus scrape, Livo, 2004; swab versus toe clip, Hyatt et al., 2007). To avoid potential contamination of the collected tissue, we adhered scrupulously to clean procedures in the field for capturing, handling and sample collec- tion, including single-use (=single animal) gloves, and single-use containers. Each vial was sealed in an individual plastic bag. Samples were sent to Pisces Molecular (Boulder, $\mathrm{CO}$ ) where polymerase chain reaction (PCR) techniques (Annis et al., 2004 modified by J. Wood, Pisces Molecular, Boulder, CO, personal communication) were used to detect $B d$. This technique does not differentiate between the simple presence of the fungus on the skin of the amphibian and a clinical infection that is affecting the animal's health (Smith, 2007).

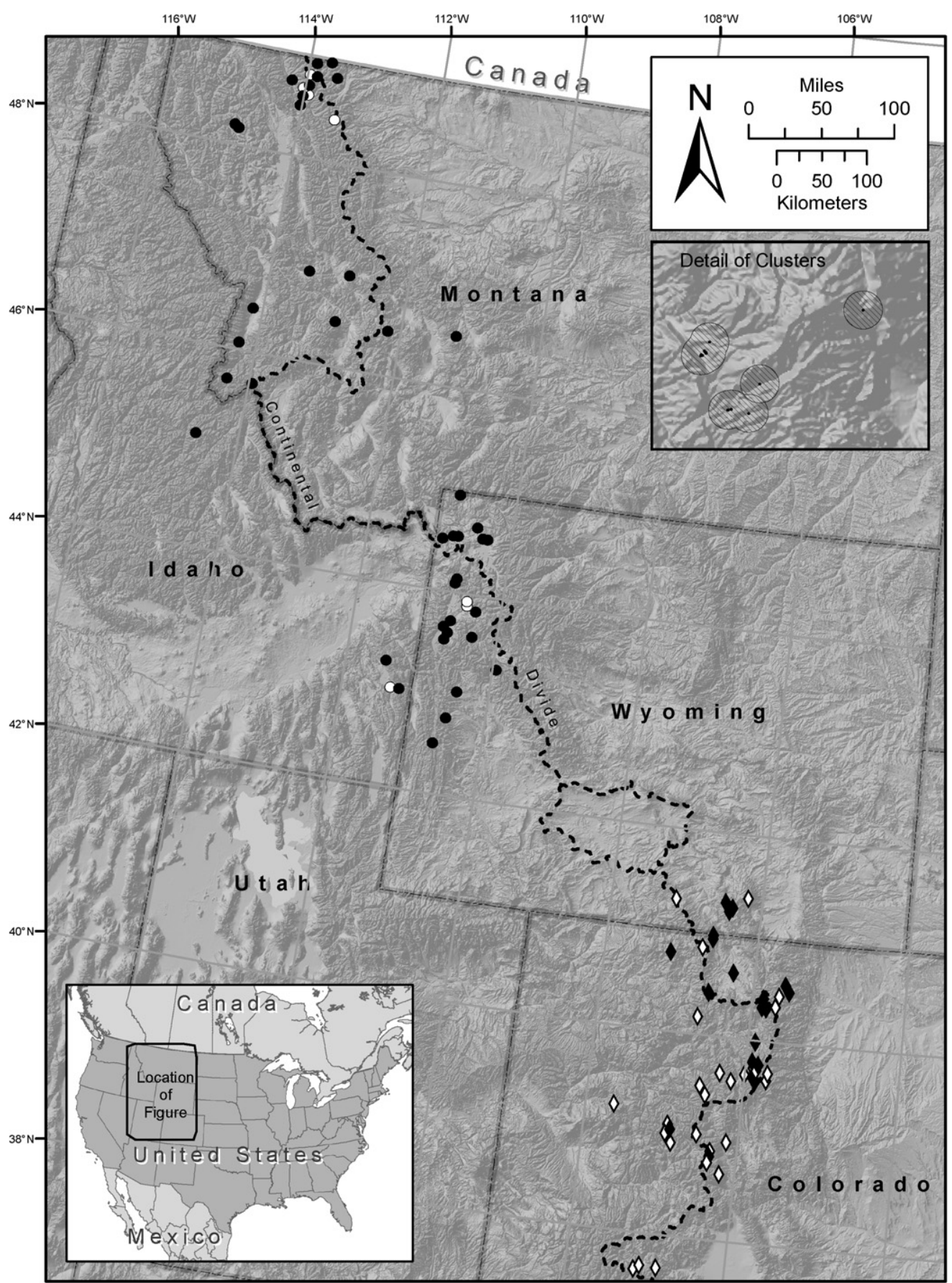

Fig. 1 - Map of clusters sampled along the Continental Divide (- - ). Clusters $(n=97)$ are composed of boreal toad breeding sites (=sampling sites). Sites were grouped such that sites closer than $3 \mathrm{~km}$ formed a cluster. However, buffer zones less than $6 \mathrm{~km}$ apart may overlap (e.g., clusters in detail). Diamonds indicate southern clusters, squares indicate northern clusters; filled symbols are $B d$ positive clusters, open symbols are $B d$ negative clusters. 


\subsection{Data analysis}

Sample locations were considered individual sites only if they were separated from other sample locations by $\geqslant 3 \mathrm{~km}$. If sample locations were $<3 \mathrm{~km}$ from one another, they were merged into a cluster formed by the overlap of each $3-\mathrm{km}$ buffer zone and the center of the cluster determined using GIS (ARCGIS 9.0, ESRI Corp, Redlands, CA) (Fig. 1). By pooling individual toads (=results) from sites within clusters, we increased our sample size at each cluster (Table 1), thus reducing potential false negative results (i.e., reporting $\mathrm{Bd}$ was absent when it was actually present) and increasing the independence between our sample units (Petranka et al., 2004). Although we have observed boreal toads traveling $>6 \mathrm{~km}$ between breeding sites (E.M. personal observation), we chose $3 \mathrm{~km}$ as a buffer distance because this represents approximately twice the mean maximum one-way migration distance of boreal toads published in other studies (Muths, 2003; Bartelt et al., 2004).

We analyzed the occupancy of $B d$ in 97 clusters, including 89 clusters with boreal toads and 8 clusters where other species were swabbed as surrogates because toads were not found. Eight clusters contained samples from 2 or more species. We did not examine prevalence (the number of cases of a disease in a defined population at a particular point in time; sensu Hunter, 1997), because we were not confident that the presence of $\mathrm{Bd}$ isolated from the skin of a small number of animals in a cluster is an accurate measure of prevalence of $B d$ in a population. Furthermore, detection of Bd via PCR in a population is strongly influenced by season and tempera-

Table 1 - Sampling effort: Number of clusters and sites; number of samples tested for Batrachochytrium dendrobatidis

\begin{tabular}{lcccc} 
Group & $\begin{array}{c}\text { No. of } \\
\text { clusters }\end{array}$ & $\begin{array}{c}\text { No. of } \\
\text { sites }\end{array}$ & $\begin{array}{c}\text { No. } \\
\text { samples } \\
\text { tested }\end{array}$ & $\begin{array}{c}\text { Median no. } \\
\text { of samples/cluster } \\
\text { (range) }\end{array}$ \\
\hline Northern & & & & $6(1-47)$ \\
Montana & 24 & 107 & 225 & $4(2-8)$ \\
Idaho & 4 & 10 & 18 & $7(1-86)$ \\
Wyoming & 21 & 45 & 225 & \\
Southern & & & & $13(1-134)$ \\
Colorado & 43 & 83 & 752 & $4(1-12)$ \\
Wyoming & 5 & 16 & 29 & $7(1-134)$ \\
Total & 97 & 257 & 1248 & \\
\hline
\end{tabular}

ture (Kriger and Hero, 2007) and we did not randomize the timing of sampling.

We plotted mean temperatures (minimum and maximum) during the active season for all clusters and placed our data within the context of what is known about temperature tolerances of $B d$ in the laboratory (Piotrowski et al., 2004). T-tests were used to compare mean temperature values between the northern and southern portions of the continental divide transect.

We used logistic regression to assess the effect of selected environmental variables (date, elevation, and temperature) on occurrence. The number of samples collected at each cluster was modeled as a measure of effort. Potential over-dispersion in the data was assessed using the deviance/d.f. value for the most parameterized model. We used Akaike's information criterion corrected for small sample sizes ( AIC $_{\mathrm{c}}$ ) and Akaike weights to determine which model best reflected our data (Burnham and Anderson, 2003). We also assessed the probability of observing a false negative result by first computing $p\left(=n_{\mathrm{i}} / n\right)$ for each cluster where $B d$ was detected; where $p=$ the probability of the fungus occurring, $n_{i}=$ the number of positive samples and $n=$ the total number of samples. Then we calculated a mean value for $p\left(=p^{*}\right)$ for all clusters and used this value to calculate the probability of a false negative at clusters where we did not detect the fungus $\left(1-p^{*}\right)^{\mathrm{n}}$. Finally, we examined the sensitivity of our results to this potential error (false negative) by re-assigning a random selection of potential false negative clusters (based on the probability described above) to positive and re-assessing the top model using a standard bootstrapping approach (1000 iterations). All analyses were conducted in SAS (SAS Institute, 2003) except the bootstrapping, which was programmed in $R$ (www.r-project.org/).

\section{Results}

DNA from Bd was isolated from all 6 species sampled (Table 2). Although the sample size for some species was very small, boreal toads had the lowest overall proportion of individuals that tested positive for $\mathrm{Bd}$. This pattern was influenced strongly by samples from the southern region of our study area, where only $10 \%$ of boreal toads tested positive for $\mathrm{Bd}$ compared with $46 \%$ in northern region (Table 3 ).

We detected Bd in $64 \%$ of the 97 clusters sampled (Table 3). Batrachochytrium dendrobatidis was detected from the lowest $(37.6 \mathrm{~N})$ to the highest $(48.6 \mathrm{~N})$ latitudes and across a range of elevations (1030-3550 m) (Fig. 3). Although Bd was detected

Table 2 - Summary of Batrachochytrium dendrobatidis $(B d)$ results from 6 species tested

\begin{tabular}{|c|c|c|c|c|c|c|}
\hline Species & States & $\begin{array}{l}\text { No. of } \\
\text { clusters }\end{array}$ & $\begin{array}{l}\text { No. of individuals } \\
\text { sampled }\end{array}$ & $\begin{array}{l}\text { No. of individuals } \\
\text { Bd positive }\end{array}$ & $\begin{array}{l}\text { No. of individuals } \\
\text { Bd negative }\end{array}$ & $\begin{array}{l}\text { Percent of individuals } \\
\text { Bd positive }\end{array}$ \\
\hline Ambystoma tigrinum & WY & 2 & 2 & 1 & 1 & 50 \\
\hline Bufo boreas & ID, CO, MT, WY & 89 & 1151 & 265 & 886 & 23 \\
\hline Pseudacris maculata & $\mathrm{CO}, \mathrm{WY}$ & 7 & 14 & 6 & 8 & 43 \\
\hline Rana luteiventris & ID, MT, WY & 12 & 50 & 20 & 30 & 40 \\
\hline Rana pipiens & $\mathrm{CO}$ & 1 & 4 & 3 & 1 & 75 \\
\hline Rana sylvatica & $\mathrm{CO}, \mathrm{WY}$ & 6 & 26 & 9 & 17 & 35 \\
\hline Total & & & 1247 & 304 & 943 & 24 \\
\hline
\end{tabular}




\begin{tabular}{|c|c|c|c|c|c|c|c|c|c|c|c|c|}
\hline \multirow[t]{3}{*}{ Clusters } & \multicolumn{4}{|c|}{$\begin{array}{l}\text { Average temperature during } \\
\text { study }(2002-2004)\end{array}$} & \multicolumn{4}{|c|}{$\begin{array}{l}\text { Average temperature } \\
\text { 1970-2005 ( } 35 \text { years) }\end{array}$} & \multicolumn{4}{|c|}{$\begin{array}{l}\text { Average temperature } \\
2100 \text { (predicted) }\end{array}$} \\
\hline & \multicolumn{2}{|c|}{ TempMin } & \multicolumn{2}{|c|}{ TempMax } & \multicolumn{2}{|c|}{ TempMin } & \multicolumn{2}{|c|}{ TempMax } & \multicolumn{2}{|c|}{ TempMin } & \multicolumn{2}{|c|}{ TempMax } \\
\hline & Mean & Range & Mean & Range & Mean & Range & Mean & Range & Mean & Range & Mean & Range \\
\hline \multicolumn{13}{|c|}{ Northern $(1030-2661 \mathrm{~m})$} \\
\hline $\mathrm{Bd}+(n=41)$ & 3.8 & $1.0-7.4$ & 19.7 & $15.5-25.1$ & 2.6 & $-0.2-6.5$ & 19.5 & $15.1-25.0$ & 4.3 & $-0.8-8.0$ & 23.1 & $18.7-27.8$ \\
\hline$B d-(n=8)$ & 4.4 & $2.2-6.4$ & 19.2 & $15.3-21.1$ & 3.2 & $1.7-6.0$ & 18.8 & $14.7-20.9$ & 5.0 & $2.7-7.0$ & 22.7 & $18.2-24.6$ \\
\hline All sites North & 3.9 & $1.0-7.4$ & 19.6 & $15.3-25.1$ & 2.7 & $-0.2-6.5$ & 19.4 & $14.7-25.0$ & 4.4 & $-0.8-8.0$ & 23.0 & $18.2-27.8$ \\
\hline \multicolumn{13}{|c|}{ Southern $(2458-3805 \mathrm{~m})$} \\
\hline$B d+(n=21)$ & 1.9 & $-0.6-4.4$ & 18.6 & $15.2-21.5$ & 1.4 & $-2.3-3.8$ & 17.3 & $13.3-20.9$ & 3.9 & $2.3-5.6$ & 21.1 & $15.7-24.6$ \\
\hline $\mathrm{Bd}-(n=27)$ & 1.5 & $1.1-6.2$ & 16.8 & $15.3-19.9$ & 0.2 & $-3.1-5.9$ & 15.3 & 13.5-19.7 & 3.2 & $1.3-6.2$ & 19.5 & $14.8-24.7$ \\
\hline All sites South & 1.6 & $-0.6-6.2$ & 17.8 & $15.2-21.5$ & 1.1 & $-2.3-5.9$ & 16.2 & $13.3-20.9$ & 3.5 & $1.3-6.2$ & 20.2 & $14.8-24.7$ \\
\hline
\end{tabular}

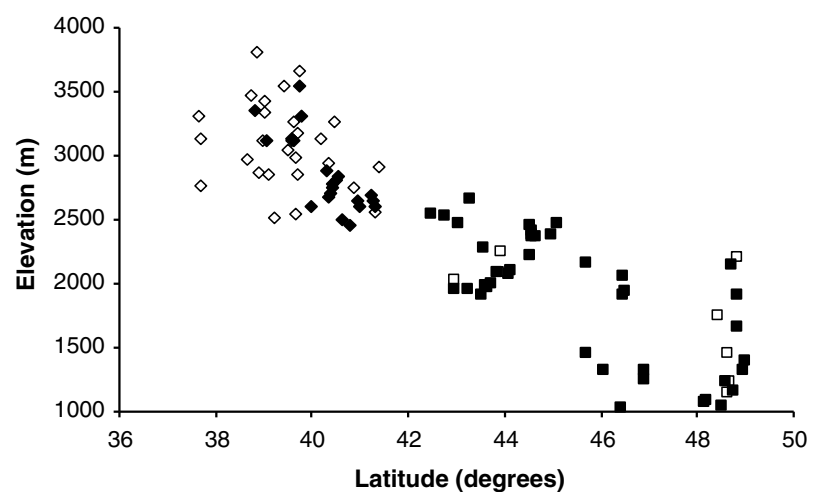

Fig. 2 - Clusters plotted relative to elevation and latitude illustrating that boreal toad sites (=clusters) at lower latitudes tend to be at higher elevations. Diamonds indicate southern clusters, squares indicate northern clusters; filled symbols are $B d$ positive clusters, open symbols are $B d$ negative clusters.

from low to high latitudes, geographical differences between the northern and southern regions are clear (Fig. 2), with sites in southern clusters (lower latitudes) occurring at higher elevations than sites in northern clusters. This pattern may reflect putative species differences predicted for Bufo boreas in the Rocky Mountains (e.g., Goebel, 2005). As expected, maximum and minimum temperatures at high elevation clusters were lower than at low elevation clusters (Table 3). Mean maximum temperatures at southern clusters where $\mathrm{Bd}$ was detected were at the lower limit of the optimal or "faster" growth zone $\left(17-25^{\circ} \mathrm{C}\right)$ as defined by Piotrowski et al. (2004). Mean maximum temperatures at southern clusters where the fungus was not detected were, on average, $2^{\circ}$ colder.

Plots of the temperature data indicate that all clusters have daily minimum temperatures within the reduced growth zone $\left(<17^{\circ} \mathrm{C}\right)$ and $84 \%$ of these experience minimums $<4{ }^{\circ} \mathrm{C}$. Forty-two percent of clusters have daily maximum temperatures in the reduced growth zone. Mean maximum temperature at southern clusters during the active season was lower than the mean maximum temperature at northern

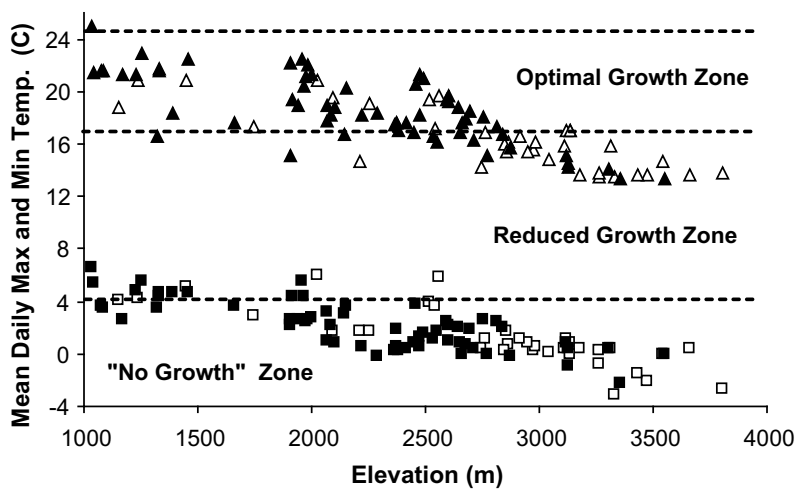

Fig. 3 - Mean daily maximum (triangles) and minimum (squares) temperatures at clusters. $10-25^{\circ} \mathrm{C}$ is suitable for growth of Batrachochytrium dendrobatidis; growth is optimal between 17-25 ${ }^{\circ} \mathrm{C}$ and slower between 4-10 ${ }^{\circ} \mathrm{C}$. (Piotrowski et al., 2004). Berger et al. (2004) reported that pathogenicity of $\mathrm{Bd}$ decreased at $23^{\circ} \mathrm{C}$.

clusters $(T=-7.238$, d.f. $=95, P<0.0001)$ and the mean minimum temperature at southern clusters during the active season was lower than the mean minimum temperature at clusters in the north ( $T=-5.783$, d.f. $=95, P<0.0001$ ) (Table $3)$. Of the clusters where $B d$ was detected $(n=62), 44 \%$ experienced daily mean maximum temperatures greater than $17^{\circ} \mathrm{C}$. In contrast, clusters where $B d$ was not detected $(n=35)$, only $11 \%$ experienced daily mean maximum temperatures greater than $17^{\circ} \mathrm{C}$ (Fig. 3).

The model best supported by the data, as indicated by Akaike weights and $\triangle \mathrm{AIC}_{\mathrm{c}}$ (Table 4) was: $\mathrm{Bd}$ occurrence $\sim 4.083+0.960$ (Region) -0.006 (Elev) -0.051 (Julian Day) + 0.479 (TempMax) -0.574 (TempMin) +0.000 (Elev $\times$ Julian Day). Confidence intervals (95\%) for estimates for TempMax and TempMin did not overlap zero (Table 5). The over-dispersion factor for the most parameterized model was 1.07.

Our cluster-level detection probability for Bd was $>65 \%$ and the probability of a false negative (assigning a cluster as negative when it was really positive) was $11 \%$ (4 of 35). TempMax, 


\section{Table 4 - Models and $\mathrm{AIC}_{\mathrm{c}}$ results}

\begin{tabular}{|c|c|c|c|c|}
\hline Model & Number of Parameters (K) & $\mathrm{AIC}_{\mathrm{c}}$ & $\Delta \mathrm{AIC}_{\mathrm{c}}$ & Akaike weight \\
\hline BdOcc $\sim$ Elev + JulianDay + Elev $\times$ JulianDay + Region + TempMax + TempMin & 8 & 112.494 & 0.000 & 0.652 \\
\hline BdOcc $\sim$ Elev + JulianDay + Elev $\times$ JulianDay + Region + TempMax & 7 & 115.179 & 2.685 & 0.170 \\
\hline BdOcc $\sim$ Elev + JulianDay + Elev $\times$ JulianDay + Region & 6 & 116.215 & 3.721 & 0.101 \\
\hline BdOcc $\sim$ Elev + JulianDay + Elev $\times$ JulianDay + Region + TempMin & 7 & 116.785 & 4.291 & 0.076 \\
\hline
\end{tabular}

$\mathrm{N}=97$ for all models. Bd Occ = Bd Occurrence; Elev = Elevation in meters; Region = North or South; TempMax = mean maximum temperature; TempMin = mean minimum temperature. All models included Effort $=$ number of samples collected for each cluster.

\begin{tabular}{|c|c|c|c|c|}
\hline & Estimate & S.E. & $\begin{array}{c}\text { Lower } \\
\text { 95\% C.I. }\end{array}$ & $\begin{array}{c}\text { Upper } \\
95 \% \text { C.I. }\end{array}$ \\
\hline Intercept & 4.0829 & 12.0871 & -19.3031 & 28.4256 \\
\hline Region & 0.9599 & 0.9308 & -0.8451 & 2.8498 \\
\hline Elevation & -0.0056 & 0.0039 & -0.0140 & 0.0016 \\
\hline Julian Day & -0.0508 & 0.0519 & -0.1569 & 0.0482 \\
\hline TempMax & 0.4785 & 0.1981 & 0.1106 & 0.8955 \\
\hline TempMin & -0.5742 & 0.2633 & -1.1201 & -0.731 \\
\hline Elevation $\times$ Julian Day & 0.0000 & 0.0000 & -0.0000 & 0.0001 \\
\hline Effort & 0.0191 & 0.0149 & -0.0081 & 0.0541 \\
\hline
\end{tabular}

TempMin, Elev and Effort were the variables least affected by a potential $11 \%$ misclassification of negative clusters. For these variables, the magnitude of the parameter estimate and the sign did not change. The mean value produced by the simulations was similar to the modeled parameter estimate. Estimates for other model parameters (Elev $\times$ Julian Day, Region, Julian Day, Intercept,) switched signs ( $<1 \%,<1 \%$, $2 \%$, and $22 \%$ ) of the 1000 iterations, respectively). Therefore, the model is relatively robust to misclassification of negative clusters especially for the two variables of interest, TempMax and TempMin.

\section{Discussion and conclusions}

We found that $B d$ is widespread in the Rocky Mountains from northern Montana to southern Colorado. Batrachochytrium dendrobatidis was documented at a higher proportion of low versus high elevation boreal toad breeding sites. Our results suggest that, in the higher elevations of the temperate zone, the occurrence or persistence of $B d$ is limited by temperature which is constrained by elevation. The positive relationship between the occurrence of $\mathrm{Bd}$ and maximum daily temperatures indicates that, in the Rocky Mountains (1) maximum ambient temperatures rarely get warm enough for $B d$ to be fully successful and (2) there may be threshold temperatures (minima and maxima) that reduce the probability of $\mathrm{Bd}$ occurrence.

One-way to explain the patterns we observed is to examine fundamental niche models that predict the occurrence of $B d$ worldwide and suggest that temperature and precipitation are important in determining where the fungus may occur (Ron, 2005). Most studies (which are almost entirely from tropical regions) have focused on maximum temperatures exceeding the tolerance levels of the fungus (e.g., Pounds et al., 2006; Drew et al., 2006). In the Rocky Mountains, ambient temperatures are rarely high enough to be lethal to the disease (i.e., $30^{\circ} \mathrm{C}$, Piotrowski et al., 2004) such that low maximum temperatures in the Rocky Mountains, particularly at higher elevations, may actually limit the success of Bd. Conversely, in Australia, frogs experiencing cooler temperatures may be less resilient to stressors and those farther from the equator (higher latitudes) carry more zoospores of $B d$ than frogs closer to the equator (Kriger et al., 2007). Kriger et al. (2007) also conclude that while optimal temperatures may occur at high-elevations in the tropics, high-elevations in temperate areas are too cold to support significant populations of Bd. Our data support this hypothesis.

Alternatively, ambient air temperature may not be a good predictor of $\mathrm{Bd}$ occurrence because it may not reflect water temperatures. For example, Seimon et al. (2006) argue that subfreezing temperatures and large diurnal temperature fluctuations do not limit the pathogenicity of $B d$, positing instead that solar heating of small ponds may provide the thermal opportunities for Bd in an otherwise cool environment. Furthermore, ambient air temperatures are not necessarily correlated with operative body temperature of individual toads. Amphibians are capable of thermal regulation by microclimate selection and behavior and adult anurans are capable of clearing themselves of $B d$ when they can maintain elevated body temperatures for several hours (Woodhams et al., 2003). Boreal toads are able to raise body temperatures above the lethal limit of $\mathrm{Bd}\left(25^{\circ} \mathrm{C}\right)$ by basking (Bartelt and Peterson, 2005) and they have been observed basking at high-elevations (Muths and Corn, 1997). However, we emphasize that the air temperature data used in our analysis are 35 year averages providing a view of climate rather than a short term weather snapshot and illustrating what the fungus would encounter over generations, likely affecting its persistence. Our study focuses on the patterns at a regional scale and does not attempt to predict situations at specific sites.

Another possible explanation for the low number of $\mathrm{Bd}$ observations at high-elevations is the relative topographic position of sites in a particular drainage. For example, in the Rocky Mountains, the fundamental niche model for Bd (Ron, 2005) predicts a mosaic pattern of occurrence. We suggest that this result is caused by drainage networks and steep topography in the region and that this feature may be key in predicting $\mathrm{Bd}$ occurrence. Whereas the absolute elevation affects environmental temperatures, the relative elevation and position within a particular drainage may also be a predictor of $B d$ infection in toad populations. Because $B d$ is an 
aquatic pathogen it may have difficulty moving upstream in mountain systems and therefore be less likely to occur in headwater wetlands. For example, in Gunnison County, Colorado, boreal toads disappeared (coincident with $B d$ observations (Jackson, 2005)) from much of the lower East River drainage in the 1970s (Carey, 1993), while at the headwaters of the same drainage (Copper Creek tributary, $3446 \mathrm{~m}$ elevation), an extant toad population has tested negative for $\mathrm{Bd}$ since 2001 (Jackson, 2005). This site is $>400 \mathrm{~m}$ higher than nearby sites where toads disappeared or are currently $\mathrm{Bd}$ positive; suggesting that relative elevation within a drainage plays a role in the potential for invasion by this fungus.

The effects of global climate change on species ranging from mammals to grasses are well documented and appear to be coherent in pattern (Parmesan and Yohe, 2003; Root et al., 2003) and regional manifestations of recent climate change are evident (e.g., Parmesan, 2006; Logan et al., 2003; Barber et al., 2000). Concerns are especially relevant to high latitude and high elevation locations because that is where effects on organisms are likely to be most dramatic (e.g., Schneider et al., 2007; Wagner, 2003). Pounds et al. (2006) discussed the importance of elevation with respect to changing environmental conditions ascribed to global warming and notes that "low temperatures as well as high ones may limit the impact of Bd." More broadly, Kriger and Hero (2007) pointed out that temperatures vary across seasons, elevations and latitudes and that such variation, in concert with the sensitivity of amphibian immune systems and the thermal restrictions of $B d$, are likely important in the ecology of this host-pathogen interaction. In North America, Longcore et al. (2007) report that ambient temperatures in the Northeastern United States vary between high enough and low enough to limit growth of $B d$, further emphasizing the importance of local conditions. Our data provide evidence that the distribution or persistence of this disease in the Rocky Mountains is limited by temperature.

As global warming progresses, Bd may increase in occurrence and perhaps in the severity of its impact on Rocky Mountain amphibians. Predicted ambient temperatures at our study sites by 2100 are expected to fall within the optimal growth zone for $B d$, reducing the temperature limitations to Bd growth and allowing possible range expansion of the pathogen to higher elevations. Specifically, predictions for the Rocky Mountains include warmer night-time temperatures, higher temperatures during the winter and reduced snowpacks (Wagner, 2003) resulting in a thermal regime at higher elevations that might be more conducive to $B d$ growth and persistence. At our study sites, average daily maximum temperatures at $\mathrm{Bd}$ positive clusters are predicted to increase at least $3.6^{\circ} \mathrm{C}$, while average daily minimum temperatures are predicted to increase at least $1.7^{\circ} \mathrm{C}$ (Table 3). The average temperatures during the years of the study (2002-2004) are greater than the 35 year average temperatures (Table 3) suggesting that warming is already occurring.

The distribution of $B d$ in this region highlights a paradox. We found that the occurrence of Bd was lower in the southern (and higher elevation) portion of the study area, yet boreal toad populations in the Southern Rocky Mountains are declining (Corn et al., 1989; Carey, 1993; Stuart and Painter, 1994; Muths et al., 2003). In contrast, toad populations in the northern portion of the study area appear to be stable. Possible explanations for this paradox include previous outbreaks of $\mathrm{Bd}$ resulting in resistant populations, or higher susceptibility to $B d$ with consequent local extirpations in the southern portion of the study area. For example, Briggs et al. (2005) point out that long-term persistence of $B d$ at a breeding pond may depend on some individuals surviving and carrying the fungus past metamorphosis (i.e., resistance). Susceptibility to chytridiomycosis may also vary with genetic differences among boreal toad populations. Recent genetic evidence, supported by habitat characteristics (e.g., elevational range), suggests that populations of boreal toads in the Southern Rocky Mountains represent a distinct species or subspecies (Goebel, 2005). In addition to resistance and susceptibility issues in the host, there may be differences in the pathogenicity of Bd strains within a region (Berger, 2005; Morgan et al., 2007). Alternatively, aspects of local environments may affect host-pathogen interactions differently. For example, toads in the Colorado Front Range inhabit environments with elevated atmospheric nitrogen deposition (Fenn et al., 2003).

The regional-level field data presented here demonstrate that the occurrence of $B d$ varies geographically. These results are particularly important given that this study focused on breeding sites for a single species and still revealed patterns. For example, temperature considerations are likely to be critical to understanding the distribution and prevalence of $\mathrm{Bd}$ and can play a role in the selection of sites for future salvage operations (sensu Mendelson et al., 2006) and reintroductions of threatened and endangered amphibians. Increased temperatures due to global warming are likely to reduce the environmental constraints acting on the fungus, allowing it to expand its distribution into high elevation areas. In conclusion, we suggest that it is low maximum temperatures and relative geography that may actually restrict the occurrence or persistence of this pathogen in the Rocky Mountains.

\section{Acknowledgements}

Thanks to P. Cryan, B. Hossack, T. Stanley, A. Yackel-Adams, and P.S. Corn for providing comments on earlier drafts of this manuscript and B. Cade for the bootstrapping analysis. We thank B. Maxell, C. Peterson, D. Patla, and B. Turner for assistance with study site selection. We thank T. Allison, B. Hossack, B. Maxell, M. Murphy, D. Patla, and S. Speare for sharing samples with us. Numerous people assisted in the field and we especially thank C. Carey, K. Foster, M. Jones, P. Power, S. Wilcox, T. Wilcox, and J. Wood for assistance with the Colorado collections. K. Chojnacki, T. Giles and T. Fancher assisted with mapping. Thanks also to T. Davern and C. Jarnevich for help in obtaining the predictive temperature data. We acknowledge Henderson Mine, Colorado National Monument, Lost Trail National Wildlife Refuge, Boulder County Open Space, and the City of Boulder Open Space. This work was conducted under scientific collecting permits issued by Idaho Department of Fish and Game, Colorado Division of Wildlife, Montana Fish, Wildlife and Parks, Wyoming Game and Fish, and Yellowstone, Grand Teton and Rocky Mountain National Parks and was funded by the USGS Amphibian Research 
and Monitoring Initiative, the Colorado Division of Wildlife, and Great Outdoors Colorado.

\section{R E F E R E N C E S}

Annis, S.L., Dastoor, F., Ziel, H., Daszak, P., Longcore, J.E., 2004. A DNA-based assay to identify Batrachochytrium dendrobatidis in amphibians. Journal of Wildlife Diseases 40, 420-428.

Barber, V.A., Juday, G.P., Finney, B.P., 2000. Reduced growth of Alaskan white spruce in the Twentieth Century from temperature-induced drought stress. Nature 405, 668-673.

Barnett, T.P., Pierce, D.W., Hidalgo, H.G., Bonfils, C., Santer, B.D., Das, T., Bala, G., Wood, A.W., Nozaqa, T., Mirin, A.A., Cayan, D.R., Dettinger, M.D., 2008. Human-induced changes in the hydrology of the western United States. Science Advance Online Publication. doi: 10.1126/science.1152538.

Bartelt, P.E., Peterson, C.R., 2005. Physically modeling operative temperatures and evaporation rates in amphibians. Journal of Thermal Biology 30, 93-102.

Bartelt, P.E., Peterson, C.R., Klaver, R.W., 2004. Sexual differences in the movements and habitats selected by Western toads in southeastern Idaho. Herpetologica 60, 55-67.

Berger, L., 2005. Virulence of the amphibian chytrid fungus Batrachochytrium dendrobatidis varies with the strain. Diseases of Aquatic Organisms 68, 47-50.

Berger, L., Speare, R., Hines, H.B., Marantelli, G., Hyatt, A.D., McDonald, K.R., 2004. Effect of season and temperature on mortality in amphibians due to chytridiomycosis. Australian Veterinary Journal 82, 31-36.

Blaustein, A.R., Romansic, J.M., Scheessele, E.A., Han, B.A., Pessier, A.P., Longcore, J.E., 2005. Interspecific variation in susceptibility of frog tadpoles to the pathogenic fungus Batrachochytrium dendrobatidis. Conservation Biology 19, 14601468.

Bosch, J., Carrascal, L.M., Duran, L., Walker, S., Fisher, M.C., 2006. Climate change and outbreaks of amphibian chytridiomycosis in a montane area of Central Spain: is there a link? Proceedings of the Royal Society B. doi:10.1098/rspb.2006.371

Briggs, C.J., Vredenburg, V.T., Knapp, R.A., Rachowicz, L.J., 2005. Investigating the population-level effects of chytridiomycosis: an emerging infectious disease of amphibians. Ecology 86, 3149-3159.

Burnham, K.P., Anderson, D.R., 2003. Model selection and multimodel inference: a practical information-theoretic approach, second ed. Springer-Verlag, New York, USA.

Carey, C., 1993. Hypothesis concerning the causes of the disappearance of boreal toads from the mountains of Colorado. Conservation Biology 7, 355-362.

Carey, C., 2000. Infectious disease and worldwide declines of amphibian populations, with comments on emerging diseases in coral reef organisms and in humans. Environmental Health Perspectives 108, 143-150.

Carey, C., Bruzgul, J.E., Livo, L.J., Walling, M.L., Kuehl, K.A., Dixon, B.F., Pessier, A.P., Alford, R.A., Rogers, K.B., 2006. Experimental exposures of boreal toads (Bufo boreas) to a pathogenic chytrid fungus. EcoHealth 3, 5-21.

Corn, P.S., Stolzenburg, W., Bury, R.B., 1989. Acid precipitation studies in Colorado and Wyoming: interim report of surveys of montane amphibians and water chemistry. US Fish and Wildlife Service Biological Report 80 (40.26).

Corn, P., 2000. Amphibian declines: review of some current hypotheses. In: Sparling, D.W., Linder, G., Bishop, C.A. (Eds.), Ecotoxicology of Amphibians and Reptiles. SETAC Press, Pensacola, pp. 663-696.
Corn, P.S., Hossack, B.R., Muths, E., Patla, D.A., Peterson, C.R., Gallant, A.L., 2005. Status of amphibians on the continental divide: surveys on a transect from Montana to Colorado, USA. Alytes 22, 85-94.

Daly, C., Gibson, W.P., Taylor, G.H., Johnson, G.L., Pasteris, P., 2002. A knowledge-based approach to the statistical mapping of climate. Climate Research 22, 99-113.

Daszak, P., Berger, L., Cunningham, A.A., Hyatt, A., Green, D.E., Speare, R., 1999. Emerging infectious diseases and amphibian population declines. Emerging Infectious Diseases 5, 735-748.

Daszak, P., Cunningham, A.A., Hyatt, A.D., 2003. Infectious disease and amphibian populations declines. Diversity and Distributions 9, 141-150.

Drew, A., Allen, E.J., Allen, L.J.S., 2006. Analysis of climatic and geographic factors affecting the presence of chytridiomycosis in Australia. Disease of Aquatic Organisms 68, 245-250.

Fenn, M.E., Baron, J.S., Allen, E.B., Rueth, H.M., Nydick, K.R., Geiser, L., Bowman, W.D., Sickman, J.O., Meixner, T., Johnson, D.W., Neitlich, P., 2003. Ecological effects of nitrogen deposition in the western United States. BioScience 53, 404420.

Gesch, D., Oimoen, M., Greenlee, S., Nelson, C., Steuck, M., Tyler, D., 2002. The National Elevation Dataset. Photogrammetric Engineering and Remote Sensing 68, 5-11.

Goebel, A.M., 2005. Conservation systematics: The Bufo boreas species group. In: Lannoo, M.J. (Ed.), Amphibian declines: the conservation status of United States species. University of California Press, Berkeley, pp. 210-221.

Govindasamy, B., Duffy, P.B., Coquard, J., 2003. High resolution simulations global climate Part 2 Increased $\mathrm{CO}_{2}$. Climate Dynamics 21, 391-404.

Green, D.E., Converse, K.A., Schrader, A.K., 2002. Epizootiology of sixty-four amphibian morbidity and mortality events in the USA, 1996-2001. Annals of the New York Academy of Science 969, 323-339.

Hammerson, G.A., 1999. Amphibians and reptiles in Colorado, second ed. University Press and Colorado and Colorado Division of Wildlife.

Hunter, P.R., 1997. Waterborne disease: epidemiology and ecology. John Wiley and Sons.

Hyatt, A.D., Boyle, D.G., Olsen, V., Boyle, D.B., Berger, L., Obendorf, D., Dalton, A., Kriger, K., Hero, M., Hines, H., Phillott, R., Campbell, R., Marantelli, G., Gleason, F., Colling, A., 2007. Diagnostic assays and sampling protocols for the detection of Batrachochytrium dendrobatidis. Diseases of Aquatic Organisms 73, 175-192.

Jackson, T., 2005. Report on the status and conservation of the boreal toad Bufo boreas boreas in the Southern Rocky Mountains 2004. 6060 Broadway, Denver, CO 80216. Unpublished Report.

Johnson, M., Speare, R., 2003. Survival of Batrachochytrium dendrobatidis in water: quarantine and control implications. Emerging Infectious Diseases 9, 922-925.

Koch, E.D., Peterson, C.R., 1995. Amphibians and reptiles of Yellowstone and Grand Teton National Parks. University of Utah Press, Salt Lake City.

Kriger, K.M., Hero, J., 2007. Large-scale seasonal variation in the prevalence and severity of chytridiomycosis. Journal of Zoology 271, 352-359.

Kriger, K.M., Pereoglou, F., Hero, J., 2007. Latitudinal variation in the prevalence and intensity of chytrid (Batrachochytrium dendrobatidis) infection in Eastern Australia, 2007. Conservation Biology 21, 1280-1290.

Lamirande, E.W., Nichols, D.K., 2002. Effects of host age on susceptibility to cutaneous chytridiomycosis in blue-andyellow poison dart frogs (Dendrobates tinctorius). In: Proceedings of the Sixth International Symposium on the Pathology of Reptiles and Amphibians, St. Paul, MN, USA. 
Lips, K., Brem, F., Brenes, R., Reeve, J.D., Alford, R.A., Voyles, J., Carey, C., Livo, L., Pessier, A.P., Collins, J.P., 2006. Emerging infectious disease and the loss of biodiversity in a neotropical amphibian community. Proceedings of the National Academy of Science 103, 3165-3170.

Livo, L.J., 2004. Methods for obtaining Batrachochytrium dendrobatidis (BD) samples for PCR testing. In: Rogers, K.B. (Ed.), Colorado Division of Wildlife Boreal Toad Research Report 2003, pp. 64-68.

Logan, J.A., Regniere, J., Powell, J.A., 2003. Assessing the impacts of global warming on forest pest dynamics. Frontiers in Ecology and the Environment 1 (3), 130-137.

Longcore, J.R., Longcore, J.E., Pessier, A.P., Halteman, W.A., 2007. Chytridiomycosis widespread in anurans of northeastern United States. Journal of Wildlife Management 71, 435-444.

Maxell, B., Werner, K., Hendricks, P., Flath, D., 2003. Herpetology in Montana: a history, status summary, checklists, dichotomous keys, accounts for native, potentially native, and exotic species, and indexed bibliography. Society for Northwestern Vertebrate Biology, Olympia, WA.

Mendelson III, J.R., Lips, K.R., Gagliardo, R.W., Rabb, G.B., Collins, J.P., Diffendorfor, J.E., Daszak, P., Roberto Ibanez, D., Zippel, K.C., Lawson, D.P., Wright, K.M., Stuart, S.N., Gascon, C., da Silva, H.R., Burrowes, P.A., Joglar, R.L., La Marca, E., Lotters, S., duPreez, L.H., Weldon, C., Hyatt, A., Rodriguez-Mahecha, J.V., Hunt, S., Robertson, H., Lock, B., Raxworthy, C.J., Frost, D.R., Lacy, R.C., Alford, R.A., Campbell, J.A., Parra-Olea, G., Bolanos, F., Domigo, J.J.C., Halliday, T., Murphy, J.B., Wake, M.H., Coloma, L.A., Kuzmin, S.L., Stanley Price, M., Howell, K.M., Lau, M., Pethiyagoda, R., Boone, M., Lannoo, M.J., Blaustein, A.R., Dobson, A., Griffiths, R.A., Crump, M.L., Wake, D.B., Brodie Jr., E.D., 2006. Confronting amphibian declines and extinctions. Science 313, 48.

Morgan, J.A., Vredenburg, V.T., Rachowicz, L.J., Knapp, R.A., Stice, M.J., Tunstall, T., Bingham, R.E., Parker, J.M., Longcore,J.E., Moritz, C., Briggs, C.J., Taylor, J.W., 2007. Population genetics of the frogkilling fungus Batrachochytrium dendrobatidis. Proceedings of the National Academy of Science 104, 13845-13850.

Muths, E., Corn, P.S., 1997. Basking by adult boreal toads (Bufo boreas boreas) during the breeding season. Journal of Herpetology 31, 426-428.

Muths, E., 2003. Homerange and movements of boreal toads in undisturbed habitats. Copeia 1, 161-165.

Muths, E., Corn, P.S., Pessier, A.P., Green, D.E., 2003. Evidence for disease related amphibian decline in Colorado. Biological Conservation 110, 357-365.

Ouellet, M., Mikaelian, I., Pauli, B.D., Rodrigue, J., Green, D.M., 2005. Historical evidence of widespread chytrid infection in North American amphibian populations. Conservation Biology 19, 1431-1440.

Parmesan, C., 2006. Ecological and evolutionary responses to recent climate change. Annual Review of Ecology, Evolution and Systematics 37, 637-669.

Parmesan, C., Yohe, G., 2003. A globally coherent fingerprint of climate change impacts across natural systems. Nature 421 , $37-42$.

Pearl, C.A., Bull, E.L., Green, D.E., Bowerman, J., Adams, M.J., Hyatt, A., Wente, W.H., 2007. Occurrence of the amphibian pathogen Batrachochytrium dendrobatidis in the Pacific Northwest. Journal of Herpetology 41, 145-149.
Petranka, J.W., Smith, C.K., Scott, A.F., 2004. Identifying the minimal demographic unit for monitoring pond-breeding amphibians. Ecological Applications 14, 1065-1078.

Piotrowski, J.S., Annis, S.L., Longcore, J.E., 2004. Physiology of Batrachochytrium dendrobatidis, a chytrid pathogen of amphibians. Mycologia 96, 9-15.

Pounds, J.A., Bustamante, M.R., Coloma, L.A., Consuegra, J.A., Fogden, M.P.L., Foster, P.N., La Marca, E., Masters, K.L., MerinoViteri, A., Puschendorf, R., Ron, S.R., Sanchez-Azofeifa, G.A., Still, C.J., Young, B.E., 2006. Widespread amphibian extinctions from epidemic disease driven by global warming. Nature 439, 161-167.

Raverty, S., Reynolds, T., 2001. Cutaneous chytridiomycosis in dwarf aquatic frogs (Hymenochirus boettgeri) originating from southeast Asia and in a western toad (Bufo boreas) from northeastern British Columbia. Canadian Veterinary Journal 42, 385-386.

Ron, S.R., 2005. Predicting the distribution of the amphibian pathogen Batrachochytrium dendrobatidis in the new world. Biotropica 37, 209-221.

Root, T.L., Price, J.T., Hall, K.R., Schneider, S.H., Rosenzweig, C., Pounds, J.A., 2003. Fingerprints of global warming on wild animals and plants. Nature 421, 57-60.

SAS Institute, 2003. SAS/STAT software. Version 9.1. SAS Institute, Inc., Cary, NC, USA.

Seimon, T.A., Seimon, A., Daszak, P., Halloy, S.R.P., Schloegel, L.M., Aguilar, C.A., Sowell, P., Hyatt, A.D., Konecky, B., Simmons, J.E., 2006. Upward range extension of Andean anurans and chytridiomycosis to extreme elevations in response to tropical deglaciation. Global Change Biology 12, 1-12.

Scherer, R.D., Muths, E., Noon, B.R., 2005. An evaluation of weather and disease as causes of decline in two populations of boreal toads (Bufo boreas). Ecological Applications 15, 21502160.

Schneider, S.H., Semenov, S., Patwardhan, A., Burton, I., Magadza, C.H.D., Oppenheimer, M., Pittock, A.B., Rahman, A., Smith, J.B., Suarez, A., Yamin, F., 2007. Assessing key vulnerabilities and the risk from climate change. Climate Change 2007: Impacts, Adaptation and Vulnerability. Contribution of Working Group II to the Fourth Assessment Report of the Intergovernmental Panel on Climate Change. In: Parry, M.L., Canziani, O.F., Palutikof, J.P., van der Linden, P.J., Hanson, C.E. (Eds.), Cambridge University Press, Cambridge, UK, pp. 779-810.

Smith, K.G., 2007. Use of quantitative PCR assays for amphibian chytrid detection: comment on Kriger et al. 2006a,b. Diseases of Aquatic Organisms 73, 253-255.

Stuart, J.N., Painter, C.W., 1994. A review of the distribution and status of the boreal toad Bufo boreas boreas, in New Mexico. Bulletin of the Chicago Herpetological Society 29, 113-116.

Wagner, F.H., 2003. Outdoor recreation and tourism. In Rocky Mountain/great basin regional climate-change assessment. In: Wagner, F.H. (Ed.), Report for the US Global Change Research Program, Utah State University, Logan, pp. 1131-1144.

Woodhams, D.C., Alford, R.A., 2005. Ecology of chytridiomycosis in rainforest stream frog assemblages of tropical Queensland. Conservation Biology 19, 1449-1459.

Woodhams, D.C., Alford, R.A., Marantelli, G., 2003. Emerging disease of amphibians cured by elevated body temperature. Diseases of Aquatic Organisms 55, 65-67. 